\title{
DOWNLANDS FARMING
}

\author{
By W. C. STAFFORD
}

Just as I am convinced that only by the full development of the downlands under a system of mixed arable farming can South Canterbury achieve the fullest production, so I am convinced that arable farming can only be built around good pasture. The world today is covered with examples of the failure to recognise this latter fact. Under conditions of suitable climate, contour, and soil, grass and crop with the grazing animal are complementary ; if any one should dominate, it is freely admitted that it should be grass. On the other hand, the fact that through the downlands climatic conditions the fullest production under an extensive grassland system cannot be achieved must also be recognised. These climatic conditions make the truly permanent high-producing pasture an impossibility. It has been found on the South Canterbury downs that the maximum effective life of a pasture under good maintenance and management is 8 years. If left longer than that, it rapidly deteriorates in carrying capacity. The basis of downs farming must therefore be, as far as we know at present, that no pasture on the downs should be, over the age of 8 -years. Under present conditions, of course, this presents to the established farmer, provided he. holds sufficient land, less difficulty without crop than it does with crop. Nevertheless, all-grass farming under the downs climatic conditions does not give maximum production, because built-up fertility through grass and animal cannot be used.

The 8 years' effective life of a pasture on the downs is a goal not easily reached. In the initial stages of the development of previously ill-farmed land, the effective life of the pastures. "the first time round" can be based only on 3 to 4 years. This means that on the cultivation journey the first time round the farm the pasture area sown annually must be double that sown when the maximum life has been attained. Unless, therefore, some means can be found to offset this heavy expenditure at a time when finance is always strained to the utmost, two things happen. An 
insufficient area of grass is sown. Lime, fertiliser, and seed expenditure is stinted, and further deterioration of the land takes place, with no increased revenue to effect improvement. The result is no progress, loss of confidence, and the reversion to low-production farming based on low expenditure. The only way, other than pouring.in more capital, that this can be overcome is to risk the introduction of cropping in the hope that the "pay as you go" system will operate. Actually there is no risk as long as this is not overdone. There is abroad an absolutely wrong idea that poorly farmed downs land is poor because it is "cropped out" ; that it; must be built up before it is cropped. It is true that crops improve as fertility is built, but the saving grace of downs land is that even the worst can by good cultivation and partial fallow be made to support crops sufficiently profitable to more than pay development expenses to put that area into good grass.

In the improvement of the downs land both in production and fertility there are three main aspects to consider:

1. The development of previously poorly farmed units.

2. The transition stage from the 3 to 4 year pasture to the 8 year pasture.

3. The maintenance and combination of arable farming on the 8 year pasture life, either as the result of development of 1 and 2 or the adaptation to arable of those areas which have been developed extensively for grazing.

Whatever the aspect is, the whole success is dependent on the adoption of a rotation or rotations and adherence to a programme. Adherence to a set programme is necessary and can be accomplished only by the availability of sufficient power, implements and labour. Whatever the rotation adopted, it must include a fallow. Without fallow in the initial stages success is impossible. A cash crop is also necessary to offset or pay for cultivation costs and grassing down. From this the simplest rotation evolves: old grass-rape-cereal-fallow-grass. There is nothing new in this; it varies only from the well-known grass-rape-wheat undersown with grass or grass put in in the autumn; the wheat is harvested by the inclusion of the fallow period, which is essential to success. Close adherence to this rotation has improved many farms, but it is 
too slow and too. incomplete as far as South Canterbury conditions 'are concerned.

The necessities in a rotation or rotations demanded in the development of downs land on the "pay as you go" system are a fallow, a profitable spring crop, a cereal, a winter feed crop, a fattening crop, and a good establishment of grass. All these demand a good knowledge of cultivation, varieties, sowing rates- and manurial requirements of crops and seeds and their optimum sowing times. Adherence to a programme through adequate power is essential.

The ideal size of a unit is 400 to 450 acres. This gives full-time employment for owner and one other. It also gives scope for development as the family grow up. Actually the size up or down does not affect development; it affects only the economics as far as manpower and expenditure on plant and implements are concerned. Much as I dislike the phrase economic unit, I will go as far as saying that under today's conditions, given adequate capital for plant and implements and sufficient for working and development costs, 250 acres could be considered sufficient for a one-man farm, if there is such a thing. The purpose of this paper is not, however, to consider subdivision as a means of increased production, or land settlement, but essentially to endeavour to show that increased production is possible on the downs by better land use. The downs by and large are sufficiently well fenced and watered, and though further decrease in the size of paddocks is necessary, the use of temporary fencing is sufficient in the early stages.

Let us consider the development of a 400 to 450 acre downs farm. In the initial stages the use of a digger plough with all its attachments is often necessary. For quick development and to fit in with the 3 to 4-year pasture, it is necessary to work two rotations independently. The first is: lea-linseed or linen flax-cereal-fallow-new grass. The second is ; lea-turnips and chou moellier-rape-cereal-fallow-new grass. The aim is to reach the full development of the first phase in 5 to 6 years. This demands a minimum of 14 paddocks and can be done by using the following as a basis. An average area of 60 acres is taken. up annually out of a lea-30 for linseed or flax and 30 for roots. Depending on size of paddocks, this figure can vary, from 70 to 50 . This means that on an average each year there are 60 acres in cereal, 30 acres in roots, 30 acres in linseed or linen flax, 30 acres in 
rape, and 60 acres fallow for new grass, the balance being in old or new grass. By the adoption of this the whole 'of the grass area would be from 1 to 4 years old between the 5th and 6th year, and the farm should have received 2 tons of lime per acre, wsing 120 tons per year, either on the fallow before sowing the new grass or in the winter after the establishment. To achieve this it is necessary that the position on the farm on the 1 January after occupation should be:

30 acres in linseed or linen flax.

30 acres in cereals.

30 acres in turnips

30 acres in rape, balance in old grass

(If there could also have been prepared 20 to 30 acres for temporary grass, say Italian and red clover, the development period would be shortened to 4 to 5 years.) By this time all the old grass under the two rotations will have been ploughed and the position will be in January 6 years after occupation:

\section{0 acres in turnips. \\ 30 acres in rape.}

30 acres in linseed or linen flax.

60 acres in cereals.

60 acres in fallow.

30 acres 4-year-old pasture, 60 acres 3-year-old pasture, 60 acres of 2-year-old pasture, 60 acres 1-year-old pasture. At this stage the pasture area is capable of grazing '750 ewes and lambs from lambing to weaning plus replacements.

This programme is a severe strain on men, machinery, and implements, especially as, during the building up, seed of ryegrass, clover, and dogstail can be taken in favourable years while sheep numbers are being built. It takes place, however, at a time when enthusiasm is at its height, when no day is too long and when nothing is a bother. It is too much to expect that such a programme could be carried on throughout the farming life and neither is it necessary, for, from the final stages of the first phase, the farm can merge without interruption of production through stage 2 into stage 3.

In the 10th year, if the programme has been adhered to, the change can be made to the 8-year pasture life without interruption and maintaining the same production. This is done by combining the two rotations to this form.: grass-linseed or' linen flax-cereal- 
turniprape-cereal-fallow-grass. At this stage part of the area out of grass can be put into peas or potatoes if the contour is suitable, for the land should now maintain such crops.

This is done by simply ploughing only one area out of grass for the spring crop and following a cereal area-for, preference, the one previously in linseedwith roots.

At this stage all the area, except 150 acres, will have been ploughed twice out of grass when the pasture is in its 3rd or 4th year. Ninety acres of the 150 acres are also ploughed in later in their 3rd or 4th year, but the other 60 acres reach 8 years before being ploughed. The area of crops remains the same, viz.:

60 acres in cereals.

30 acres in roots

30 acres in rape.

30 acres of linseed, linen flax, peas or potatoes

The area of fallow is reduced, however, to 30 acres from 60 acres, as is the annual sowing of new grass to 30 acres from 60 acres. This brings the life of the pasture to 8 years. The annual amount of lime remains the same. At this stage the pasture area is capable of grazing 1000 ewes and lambs from lambing to weaning plus replacements.

It could be said that this development could be quickened by larger areas being put through the rotations, and it is possible to do this. It must be remembered, however, that the areas dealt with in this example have been found to fit in with a two-man unit and the full, efficient use of a full range of implements and harvesting machinery. This includes a 30 horsepower and a 20 horsepower tractor and a $5 \mathrm{ft}$. header.

In the determination of the area to be ploughed out of grass each year on any unit, whatever its size, only that'area arable for all crops in the rotations can be considered. In the 1st phase the area is the total arable divided by ' 7 . In the 3rd phase it is half the arable divided by 7 .

During this change over stage complications arise. The area of roots becomes too large; the rape area is often not needed. Where once, at the beginning, 30 acres of roots was insufficient for 500 ewes, now 20 acres will do 1000 . Grass control becomes impossible during the growing months. For in South Canterbury few of us even now realise what these improved grasses and clovers will do under highfertility conditions until we are suddenly faced with 
controlling them. At this stage the introduction of cattle and the conserving of surplus pasture become necessary and there is no doubt that silage is the proper answer.

I do not know how badly or how well this has been given, but it is no fairy story ; it is being done by individuals. If it was done over the 550,000 acres of the downlands, this is what the downlands of South Canterbury would be doing.

On the Downlands alone, there would be at least another 1000 houses with a 1000 families. It would use annually :-

$$
\begin{aligned}
& 120,000 \text { tons of lime. } \\
& 8,000 \text { tons of phosphate. }
\end{aligned}
$$
fertiliser.

It could use profitably 4000 tons of nitrogenous

It could carry a million ewes and 200,000 dry sheep. Today it is carrying approximately 450,000 ewes and 100,000 dry sheep.

It could carry as well 50,000 cattle.

The whole of South Canterbury today has $1 \frac{1}{4}$ million. ewes, 700,000 dry sheep and 56,000 head of cattle. I have not been able to assess the number of cattle on the downs, as there is no information available.

The downlands would grow annually 175,000 acres of cereals, roots, rape, linseed, linen flax, peas and potatoes, of which 70,000 acres would be cereals.

Today in South Canterbury there are 136,000 acres in cereal and fodder crops, of which 38,000 are in cereals.

\section{DISCUSSION}

Q. Would the speakers comment on the taking of a greenfeed catch crop after a cereal instead of the fallow mentioned in the rotation?

A. (Stafford) : Many variations as good as the rotations suggested could be adopted. A greenfeed crop after a cereal is perfectly right. Quite a lot of farmers are doing that. Later in the development of a farm it is questionable whether the expense is warranted. I have seen many crops this year sown straight after harvest of a cereal but not utilised. However, it is a good insurance policy. Whether such an insurance policy is worth while later in the rotation is questionable. I would' prefer to fallow first time round and the fallow is essential to the establishment of grass. To quote from my paper, the rotation presents "less difficulty without a crop than it does with a crop."

Q. Would animal research people comment on the unthriftiness of lambs referred to? 
Dr. J. F. Filmer: So far as I see it Mr Hurst's diagnosis is right. See that ewes are adequately fed and so producing the full amount of milk. Most trouble can be traced to the fact that ewes are not milking well. See that pastures are such that ewes are milking well. If there is trouble, wean the lambs and give them the best pasture possible. The ewes will get the poorer feed.

Q. If barley or ryecorn grown on cultivated stubble and not used were ploughed in when it was knee high, would it be wasted?

A. I would be the last to say it was wasted, but I am not conversant enough with value of green manuring and suggest Dr Levy answer that.

E. B. Levy: I would hate to plough in anything I could get the stock to eat. There would be a great deal of energy in that feed that would enable stock to wander round the farm better than thev would without it. You would still get the manurial value in the residues. I would prefer to see anything grown on the farm eaten rather than ploughed under as a green manure.

Prof. Flay: I support Mr Stafford's rotation. He could have gone further and said the taking of a greenfeed crop does not fit in with the farm economy. When the autumn is wet it is difficult to get the crop in in time to make lamb feed'and it is a waste as far as sheep utilisation is concerned. Any humus added to the soil is an advantage, but I would nraze the greenfeed bare. When vou can get the greenfeed in in time, put it in if it can be used at lambing or just before. It is difficult to get stiff clay ready in time to sow greenfeed.

Q. We are still trying to find out why ewes go to fat and do not milk. Could Mr Hurst say something about the time of tupping in relation to this?

A. For the. first time I tried this year putting the rams out a bit earlier and I have the best lambs for many years. We will continue with this until something better is found. I think it is a question of management plus pasture composition.

Q. Has the question of the milking capacity of particular ewes been investigated as having a bearing on the trouble?

A. At Massey College there has been a great deal of work done on the milking capacity of ewes. As in certain types of dairy cows we find high milking capacity, so it may be with ewes.

Prof. A. W. Hudson: 'I support the statement in Mr Hurst's paper that it is illogical for extension workers to be dealing with plant husbandry to the exclusion of the allied animal husbandry.

Mr Smallfield: The division of the Department into different spheres is largely historical. Extension Division officers are mainly concerned with soils, crop and pasture produc- 
tion, and farm management, the last including grazing problems. The Animal Industry and Animal Research Divisions are concerned with animal health. It is very difficult to get extension officers to cover the whole field of extension work, and the position is becoming even more difficult. Officers of the respective Divisions were not completely dissociated in their spheres. Extension officers dealing with crops and plants who are up against difficulties can report to people dealing with sheep and animal nutrition. If extension officers dealt with all subjects, I do not know that farmers would be better off. What we probably want is more officers to deal with more farms more intensively.

Dr Mitchell: There is more need than ever for each officer to become a specialist. This trend will have the inevitable bad result that a whole lot of different men will have to refer problems outside their field to men who may be 50 miles away. The point revolves round giving officers more training of a wider range.

Chairman: The ideal seems to be somewhere between an allround extension officer in field and animal husbandry and an officer with a good knowledge of field work who can call on the animal husbandry man. The work calls for a man who can closely identify himself with problems in his district. There is always the difficulty of time when a problem has to be referred. The field and animal sides should trend toward each other. A deficiency of any extension service in any district is failure of farmers to establish co-operation with their field officer.

J. W. Woodcock: I deprecate the efforts of research workers to trv to nush this auestion back to the extension worker. There was the question by Mr Hurst why lambs do not fatten and he inferred that the reason might be in the type of herbage. If the research worker had an answer- to that and the field officer knew it, he would be only too pleased to carry it to the farmer.

Stafford: We have heard for many years of the benefits of a good rotation, but what a good rotation is nobody has definitely stated. All rotations have weaknesses. When I first came to South Canterbury it was all super and lime and a veterinarian attributed much of the stock trouble to all -the super and lime that was being chucked about. In one of the short rotations mentioned (with linseed) the land is out of grass for from 5 years to 5 years 8 months. On downlands this could be considered too long for South Canterbury. I purposely avoided mention of-other than cereals. Then there is the question: What would you do in a season like this?

Roots to rape is a weakness, but it has been overcome to a high degree by Club Root Resistant rape. Our Department has promising swede and turnip resistant to club root.

There is a lot of poorly farmed downlands. Ever'y week I go over at least 400 to 500 acres that is poorly farmed. In referring to the development of poorly farmed downs I am not thinking of one case-rather of the majority. 
Chairman: In these 3 papers we have had presented planned farming. All the speakers are farmers in their own right. With thought, foresight, and planning they have brought their farms up in stock carried and yields per acre. In all farm operations it is production per acre that counts; This is the summation of all the effort put in. It is worth considering, in regard to the foothills particularly,

the dependence on climatic conditions. We know we are at the mercy of rainfall particularly. The turning point in the develonment of the downlands came with a awer farming. With machinery farmers have been able to get on to the ground when it is ready. It has been a possible measure of counter to the hazard of the climate.

Prof. Flay: If we could get downlands farmers generally to do what these leading farmers have done, what great improvement we would get. 